\title{
Learning Management System Design Course And Training Institutions (Case Study: Earth Creative Institute)
}

\author{
${ }^{1}$ Cecep Kurnia Sastradipraja, ${ }^{2}$ Falentino Sembiring, ${ }^{3}$ Dery Ahmad Kamalino \\ ${ }^{123}$ Sistem Informasi, Universitas Nusa Putra, Indonesia \\ ${ }^{1}$ cecep.kurnia@nusaputra.ac.id, ${ }^{2}$ falentino.sembiring@nusaputra.ac.id, ${ }^{3}$ derykamalino@gmail.com
}

\section{ARTICLE INFO}

Article History:

Received : 12-04-2020

Revised : 02-05-2020

Accepted : 25-05-2020

Online : 30-05-2020

\section{Keywords:}

LMS; Web; LKP Bumi

Kreatif Institute

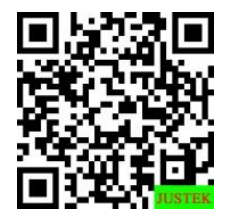

\begin{abstract}
Abstract: This research aims to design a learning management system application at LKP Bumi Kreatif Institute where the learning process in the institution is still classically carried out and does not have system support for online learning so that learning will be hampered in the event of natural disasters such as the Current Covid-19 pandemic because it requires all learning activities to be carried out at home and there is no direct interaction between students and instructors in the classroom. The process in developing applications using waterfall models includes observation studies, system modeling using UML, application construction using PHP and MySQL programming languages as database management, system testing using BlackBox, and to test application feasibility, usability testing is used by distributing questionnaires and weighting through Likert scales. Based on the results of research conducted that the application built can be implemented and able to facilitate online learning activities at the LKP Bumi Kreatif Institute, starting from the registration process, payment calculation, course administration management, students, and instructors. The results of the usability value recap show the overall attribute has an average user acceptance value of 4.27 so it can be said that the application implementation of Learning Management System in LKP Bumi Kreatif Institute has a good value of usability aspect, namely: learnability, efficiency, memorability, errors, and satisfaction.
\end{abstract}

\begin{abstract}
Abstrak: Penelitian ini bertujuan untuk merancang aplikasi sistem manajemen pembelajaran di Lembaga LKP Bumi Kreatif dimana proses pembelajaran di lembaga tersebut masih dilakukan secara klasikal dan belum memiliki dukungan sistem pembelajaran daring sehingga pembelajaran akan terhambat jika terjadi bencana alam seperti pandemi Covid-19 saat ini karena mengharuskan semua kegiatan pembelajaran dilakukan di rumah dan tidak ada interaksi langsung antara siswa dan instruktur di dalam kelas. Proses dalam pengembangan aplikasi menggunakan model waterfall meliputi studi observasi, pemodelan sistem menggunakan UML, pembuatan aplikasi menggunakan bahasa pemrograman PHP dan MySQL sebagai pengelolaan database, pengujian sistem menggunakan BlackBox, dan untuk menguji kelayakan aplikasi digunakan pengujian usability dengan menyebarkan kuisioner dan pembobotan melalui Skala likert. Berdasarkan hasil penelitian yang dilakukan bahwa aplikasi yang dibangun dapat diimplementasikan dan mampu memfasilitasi kegiatan pembelajaran daring di lembaga LKP Bumi Kreatif, mulai dari proses pendaftaran, perhitungan pembayaran, pengelolaan administrasi kursus, mahasiswa, dan instruktur. Hasil rekap nilai usability menunjukkan secara keseluruhan atribut memiliki rata-rata nilai
\end{abstract}


penerimaan pengguna sebesar 4.27 sehingga dapat dikatakan bahwa penerapan sistem manajemen pembelajaran di LKP Bumi Kreatif Institute memiliki nilai aspek usability yang baik yaitu: learnability, efficiency, memorability, errors, and satisfaction.

\section{A. LATAR BELAKANG}

Perkembangan teknologi di dunia industri semakin meningkat dari mulai era industri 1.0 sampai di era industri 4.0 (Poerwanto \& Shambodo, 2020) seperti saat ini yang mengharuskan kita memutakhirkan setiap kegiatan agar terkoneksi dengan internet (Tantoni et al., 2020), seperti halnya kegiatan di perusahaan, di rumah sakit, bahkan di dunia pendidikan sekalipun, sehingga internet sangat penting demi mempermudah setiap kegiatan tersebut .

Khususnya dalam dunia pendidikan untuk mempermudah proses pembelajaran dapat menggunakan sistem manajemen pembelajaran (Ismail \& Sinen, 2017) yang bisa menghasilkan sebuah proses sistem informasi yang mudah, cepat (Suryati, 2016), dan tak terbatas oleh waktu, seperti halnya proses pembelajaran, pengarsipan data, dan keuangan. Semua itu merupakan dampak positif dalam penggunaan internet di dunia pendidikan.

Setiap lembaga pendidikan dalam melaksanakan kegiatannya pasti memiliki proses yang berbeda-beda, seperti halnya di Lembaga Kursus Dan Pelatihan Bumi Kreatif Institute. Disini penulis mencoba menganalisis proses kegiatan yang ada di Lembaga Kursus dan Pelatihan Institute. Lembaga Kursus dan Pelatihan Bumi Kreatif Institute ini bergerak di bidang pertanian, kewirausahaan, dan ekonomi kreatif. Adapun untuk bidang pertanian yaitu pelatihan hidroponik, untuk bidang kewirausahaan yaitu pelatihan pendamping wirausaha, dan untuk ekonomi kreatif yaitu pelatihan pembuatan moci dan pelatihan pembuatan kue pesta.

Dari hasil analisis penulis dengan menggunakan metode wawancara langsung dengan pihak terkait, proses kegiatan Lembaga Kursus dan Pelatihan Bumi Kreatif Institute Sukabumi masih menggunakan cara konvensional, sehingga dalam proses pembelajaran hanya bisa dilakukan jika siswa dan instruktur melakukan tatap muka secara langsung (Widhiartha, 2009), dengan demikian tidak menutup kemungkinan ketika terjadi bencana alam seperti pandemi Covid-19 saat ini yang mengharuskan belajar di rumah (Firman \& Rahayu, 2020) sehingga mengakibatkan LKP Bumi Kreatif Institute ini tidak beroprasi. Berdasarkan hasil uraian latar belakang di atas, maka dapat dirumuskan beberapa permasalahannya sebagai berikut :

1. Bagaimana Analisis LMS di LKP Bumi Kreatif Institute.

2. Bagaimana Perancangan $L M S$ di LKP Bumi Kreatif Institute.

3. Bagaimana Implementasi Prototipe $L M S$ di LKP Bumi Kreatif Institute.

Untuk mendukung penelitian ini penulis melakukan pengkajian terhadap penelitianpenelitian terdahulu (prior research) (Shuttleworth, 2009) yang ada relevansinya dengan topik pembahasan yaitu sistem manajemen pembelajaran. Berdasarkan eksplorasi pada penelitian terkait, penulis menemukan beberapa perbedaan dengan obyek yang sedang diteliti, meskipun terdapat korelasi pembahasan, Adapun beberapa penelitian terkait diantaranya: 
1. Perancangan Learning Management System menggunakan Konsep Computer Supported Collaborative Learning (Studi Kasus : AMIK HASS Bandung). Oleh Taofik Muhammad, pada jurnal Produktif (Muhammad, 2017). Adapun penelitian tersebut dalam proses pengembangan sistem informasi menggunakan metode RUP dan tidak menggunakan sistem ulasan materi sebagai fitur pada aplikasi, sedangkan pada penelitian penulis menggunakan model waterfall dan memiliki fasilitas atau fitur untuk ulasan materi.

2. Model Pembelajaran Berbasis Learning Management System Dengan Pengembangan Software Moodle (Studi Kasus : SMA Negeri Kota Yogyakarta). Oleh Setya Raharja, dkk., pada jurnal Pendidikan (Raharja, 2014). Adapun penelitian tersebut melakukan proses pengembangan dan modifikasi LMS dengan menggunakan software Moodle dengan pengkajian kondisi software, hardware, dan SDM di SMA Negeri Kota Yogyakarta, sedangkan pada penelitian yang dilakukan penulis sesuai tahapan waterfall model dengan obyek yang berbeda.

\section{B. METODE PENELITIAN}

Metode penelitian pada proses pengembangan aplikasi Learning Management System ini adalah menggunakan metode Waterfall. Alasan Penulis menggunakan metode ini yaitu segi model pendekatan aplikasinya secara sistematis dan berurutan (Fahrurrozi \& Azhari, 2013), sehingga sistem yang dihasilkan dapat berkualitas baik. Adapun tahapan dari metode waterfall seperti pada Gambar 1 berikut ini:

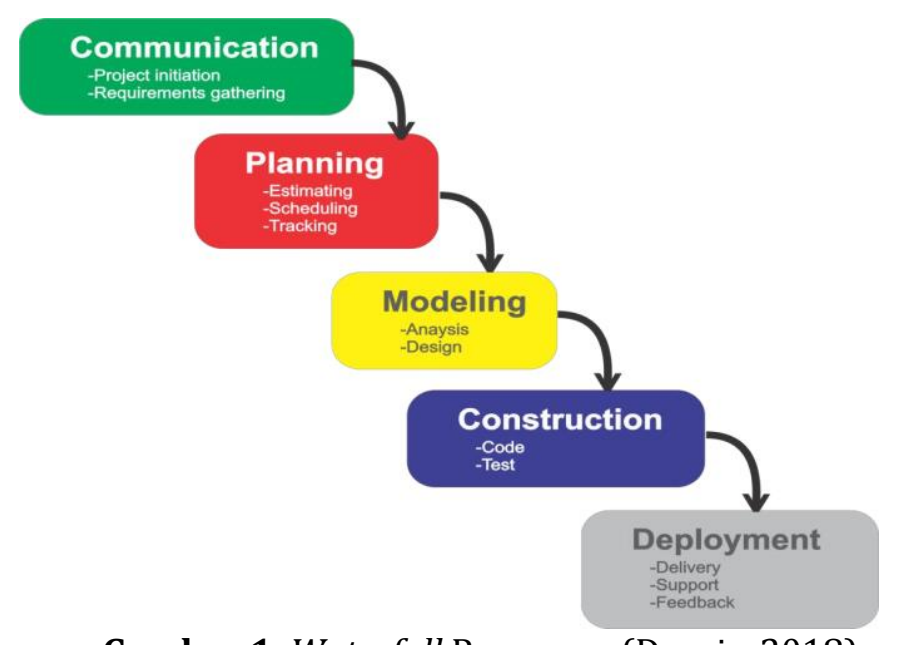

Gambar 1. Waterfall Pressman (Darnis, 2018)

Dalam melakukan analisis permasalahan penulis menggunakan metode studi observasi dan pengumpulan data dilakukan melalui proses wawancara dengan pihak terkait pada LKP Bumi Kreatif serta studi literatur dengan pengkajian terhadap obyek permasalahan yang ada relevansinya dengan penelitian yang sedang dilakukan.

Pada pendefinisian kebutuhan, analisis dan desain direpresentasikan melalui pemodelan system menggunakan UML dengan menggunakan 4 diagram diantaranya : Use case diagram, class diagram, sequence diagram dan activity diagram.

Tahap pengujian aplikasi menggunakan blackbox testing. Metode pengujian Black Box Testing dipilih karena metode pengujian tersebut tidak terlalu menfokuskan struktur logika internal (coding) pada aplikasi (Nidhra, 2012). Selain pengujian dilakukan oleh pihak pengguna, tahap pengujian ini juga dilakukan secara parsial oleh penulis sendiri. 
Dalam pengujian Usability Testing pada penelitian ini penulis melakukan penyebaran kuesioner yang diberikan langsung kepada responden. Penulis memilih 10 responden untuk dijadikan sampel, karena kuesioner merupakan instrumen pertama dalam penelitian ini. Dalam penentuan bobot pertanyaan penulis menggunakan metode skala likert dari setiap jawaban dengan lima opsi jawaban antara lain sangat setuju, setuju, netral, tidak setuju dan sangat tidak setuju (Joshi et al., 2015) (Sastradipraja \& Barokah, 2020). Dari kelima aspek usability testing penulis menyebar kuesioner dengan 10 pertanyaan yang mewakili kelima aspek tersebut kepada 10 orang responden. Pengujian Usability Testing sangat penting dilakukan untuk bahan referensi kelayakan aplikasi (Supriyatna, 2018) seperti halnya evaluasi Learning Management System pada Lembaga Kursus Bumi Kreatif Institute. Berikut merupakan gambaran populasi sampel responden dan instrumen kuesioner seperti pada tabel 1 di bawah ini:

Tabel 1. Populasi Sampel dan Instrumen

\begin{tabular}{llllll}
\hline Responden & \multicolumn{3}{l}{ Instrumen } \\
\hline No & $\begin{array}{l}\text { Jenis } \\
\text { Kelamin }\end{array}$ & Jumlah & $\begin{array}{l}\text { Jumlah } \\
\text { pertanyaan }\end{array}$ & Aspek Usability & \\
\hline 1 & L & 5 & 10 & $\begin{array}{l}\text { learnability, efficiency, } \\
\text { errors, and satisfaction }\end{array}$ & memorability, \\
\hline 2 & $\mathrm{P}$ & 5 & 10 &
\end{tabular}

Jumlah skor observasi adalah jumlah dari skor masing-masing butir pernyataan hasil observasi yang dikalikan bobot skor menurut skala Likert. Jumlah skor yang diharapkan adalah jumlah skor tertinggi yang dikalikan dengan jumlah responden.

1. $\sum$ Skor Observasi $=($ jumlah $\mathrm{x}$ skor $\mathrm{SS})+($ jumlah $\mathrm{x}$ skor $\mathrm{S})+($ jumlah $\mathrm{x}$ skor CS) + (jumlah $\mathrm{x}$ skor TS) + (jumlah $\mathrm{x}$ skor STS)

2. $\sum$ Skor yang diharapkan $=$ Jumlah skor tertinggi $\mathrm{X}$ Jumlah Responden

Perhitungan presentasi kelayakan adalah sebagai berikut :

$$
\text { Prosentase Kelayakan }=\frac{\sum \text { Skor Observasi }}{\sum \text { Skor yang diharapkan }} X 100
$$

\section{HASIL DAN PEMBAHASAN}

1. Analisis sistem (Existing)

Sebelum merancang sebuah aplikasi perlu diketahui dan diidentifikasi terlebih dahulu aplikasi yang akan di buat harus sesuai dari segi kebutuhan pengguna, fungsionalitas sistem dan dukungan lingkungan yang dibutuhkan. Dari hasil observasi langsung ke lapangan penulis menghasilkan flowmap system berjalan di LKP Bumi Kreatif Institute sebagaimana tertuang pada Gambar 2 berikut : 


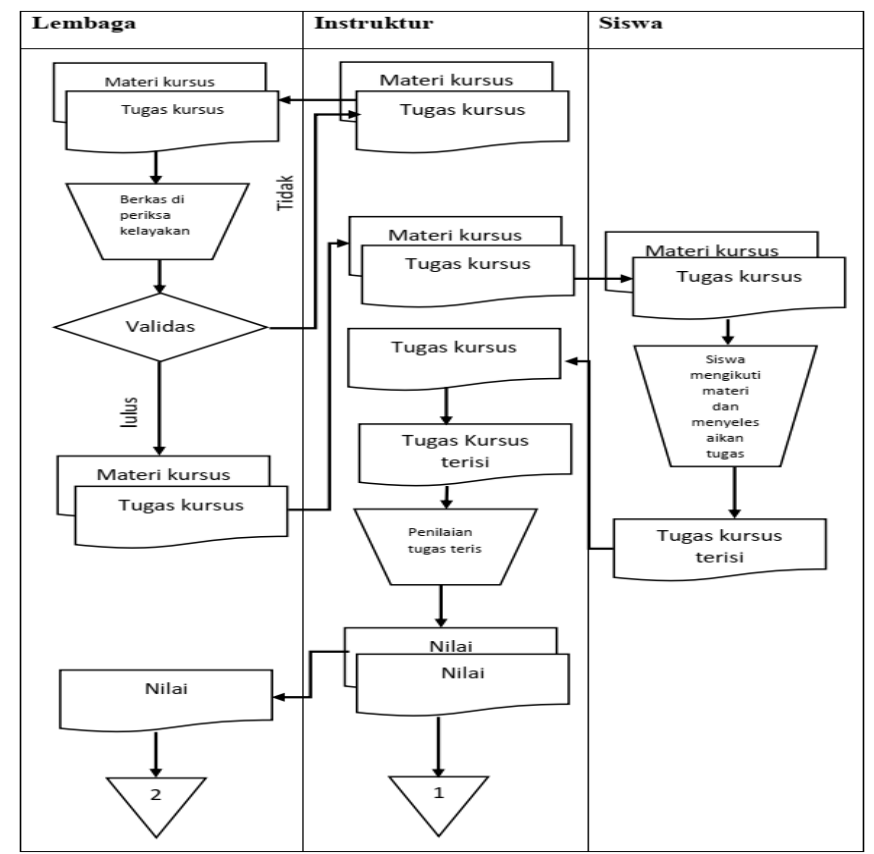

Gambar 2. Flowmaps Sistem Berjalan

\section{Analisis Sistem (Usulan)}

\section{a. Use Case Diagram}

Berdasarkan Flowmap system berjalan penulis mengusulkan perancangan Sistem Learning Management System pada LKP Bumi Kreatif Institute, maka use case diagram untuk aplikasi Learning Management System di LKP Bumi Kreatif adalah sebagaimana Gambar 3 berikut:

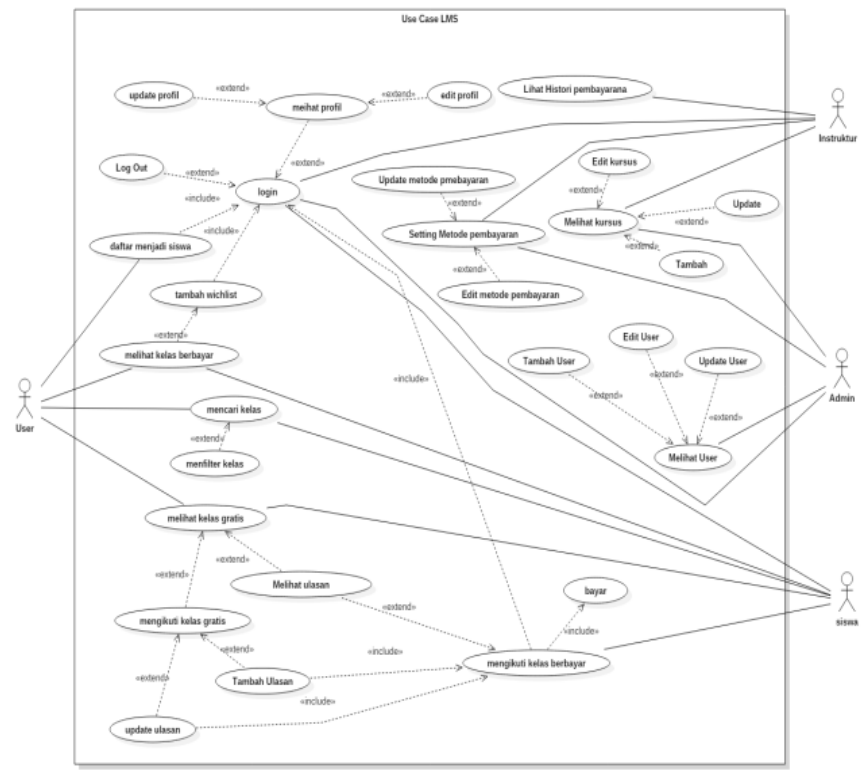

Gambar 3. Use Case Diagram

\section{b. Activity Diagram}

Activity diagram yaitu diagram yang menggambarkan aktivitas setiap actor dalam sistem yang sedang dirancang, bagaimana masing-masing alir berawal, decision yang bisa saja terjadi, dan bagaimana aktivitas berakhir. Dari semua activity diagram yang penulis buat terbagi ke dalama empat bagian yang terdiri dari: 
14 | Justek : Jurnal Sains Dan Teknologi | Vol. 3, No. 1, Mei 2020, Hal. 9-23

1) Activity Diagram Admin

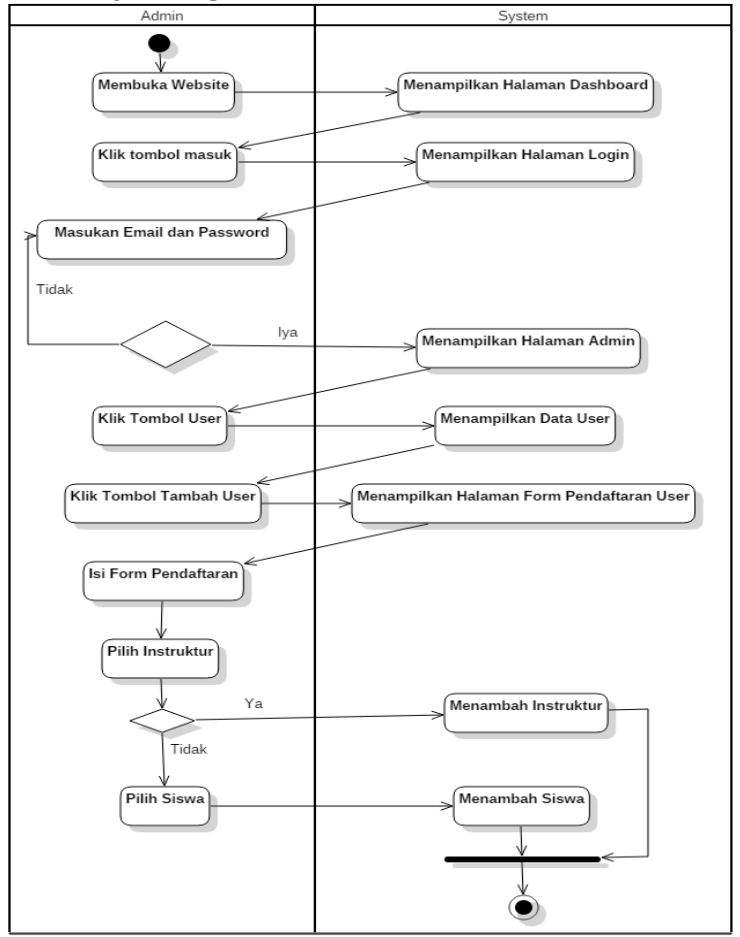

Gambar 4. Activity Diagram Admin Membuat User

2) Activity Diagram User

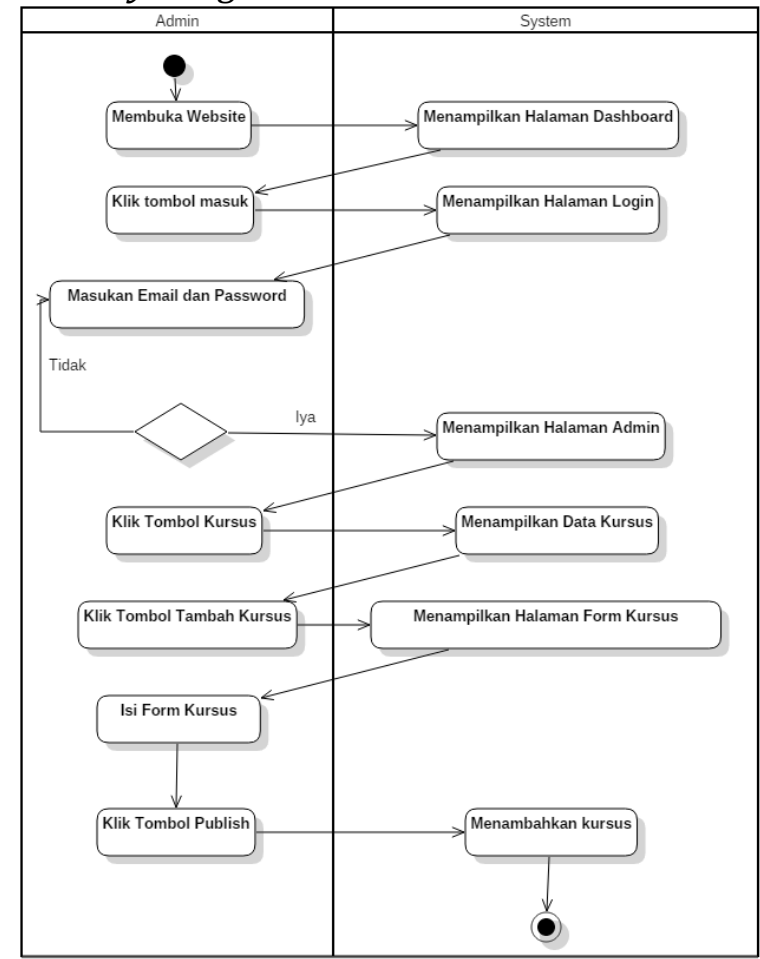

Gambar 5. Activity Diagram Admin Membuat Kursus 
3) Activity Diagram Siswa

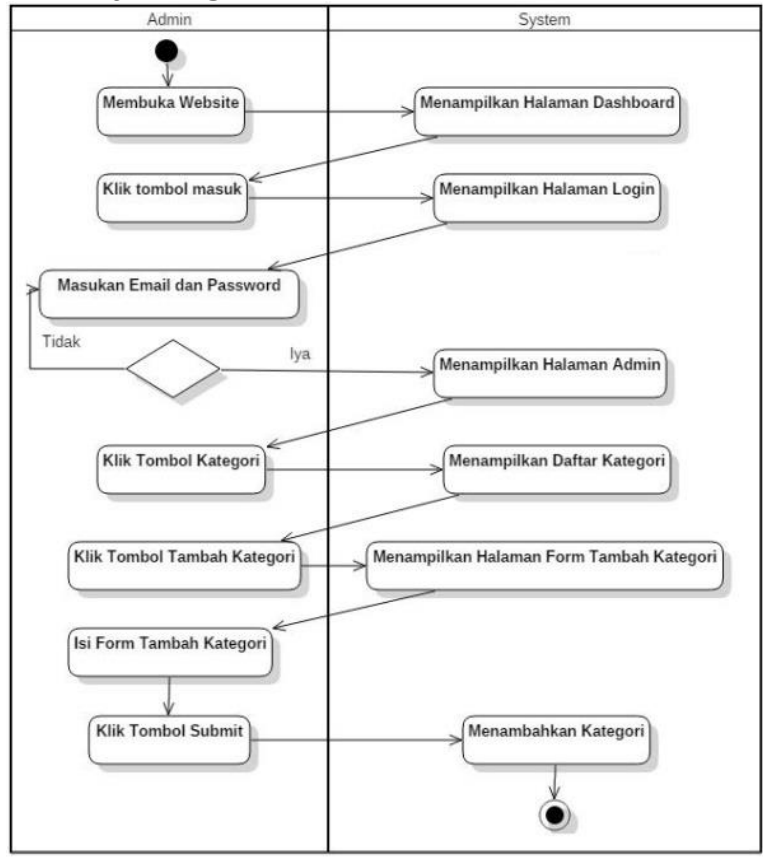

Gambar 6. Activity Diagram Admin Menambah Kategori

4) Activity Diagram Instruktur

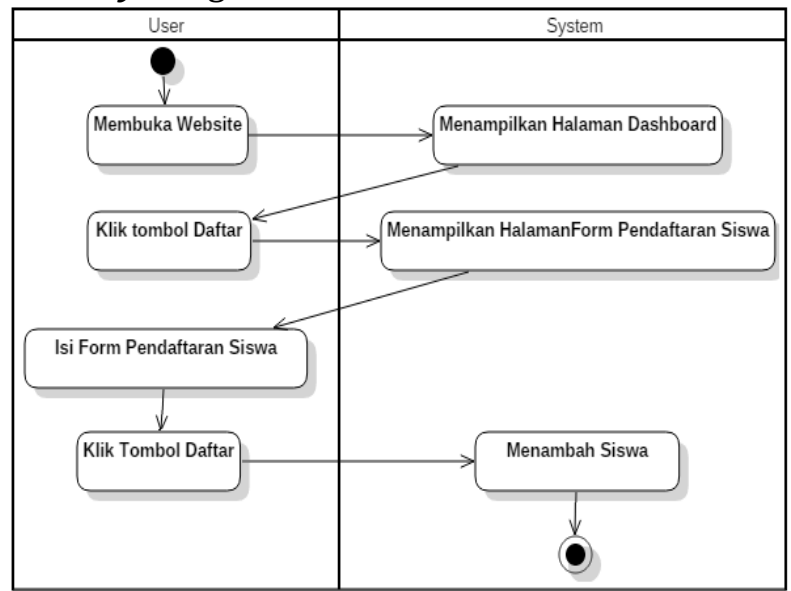

Gambar 7. Activity Diagram User Daftar Siswa

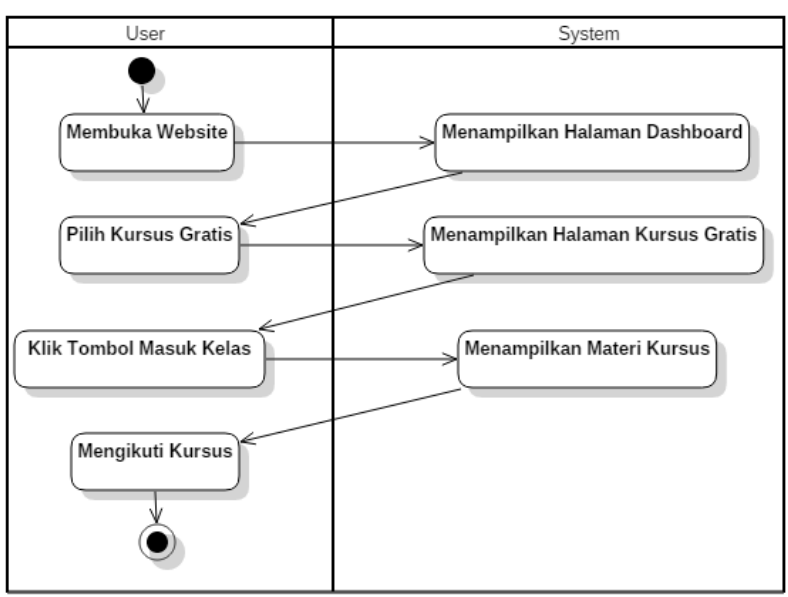

Gambar 8. Activity Diagram User Mengikuti Kursus Gratis 
16 | Justek : Jurnal Sains Dan Teknologi | Vol. 3, No. 1, Mei 2020, Hal. 9-23

5) Activity Diagram Siswa mengikuti kursus Berbayar

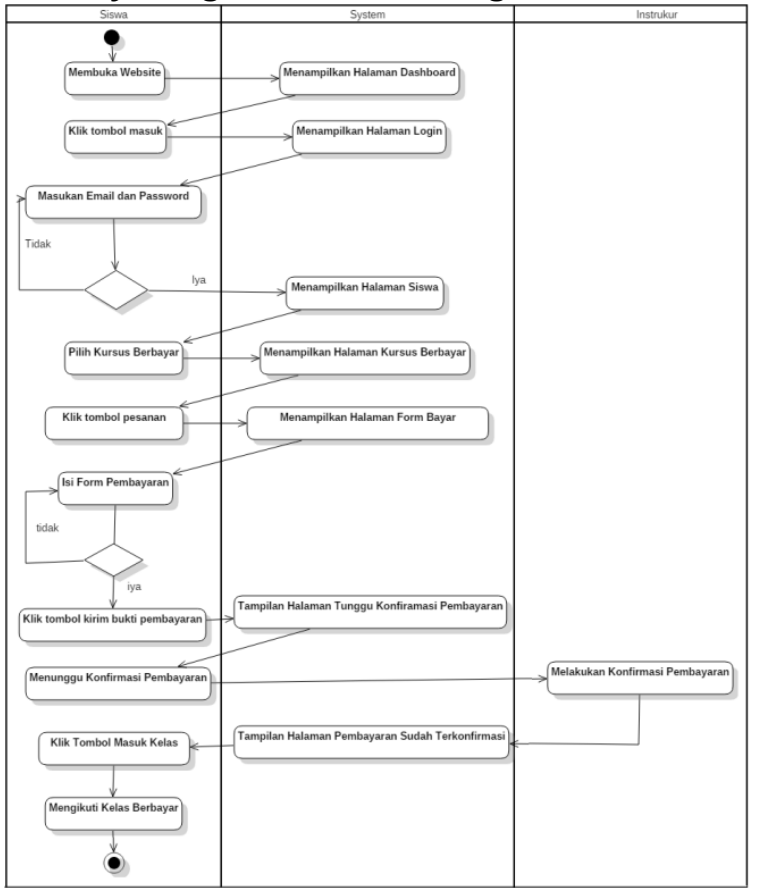

Gambar 9. Activity Diagram Siswa Mengikuti Kursus Berbayar

6) Activity Diagram Instruktur membuat kursus

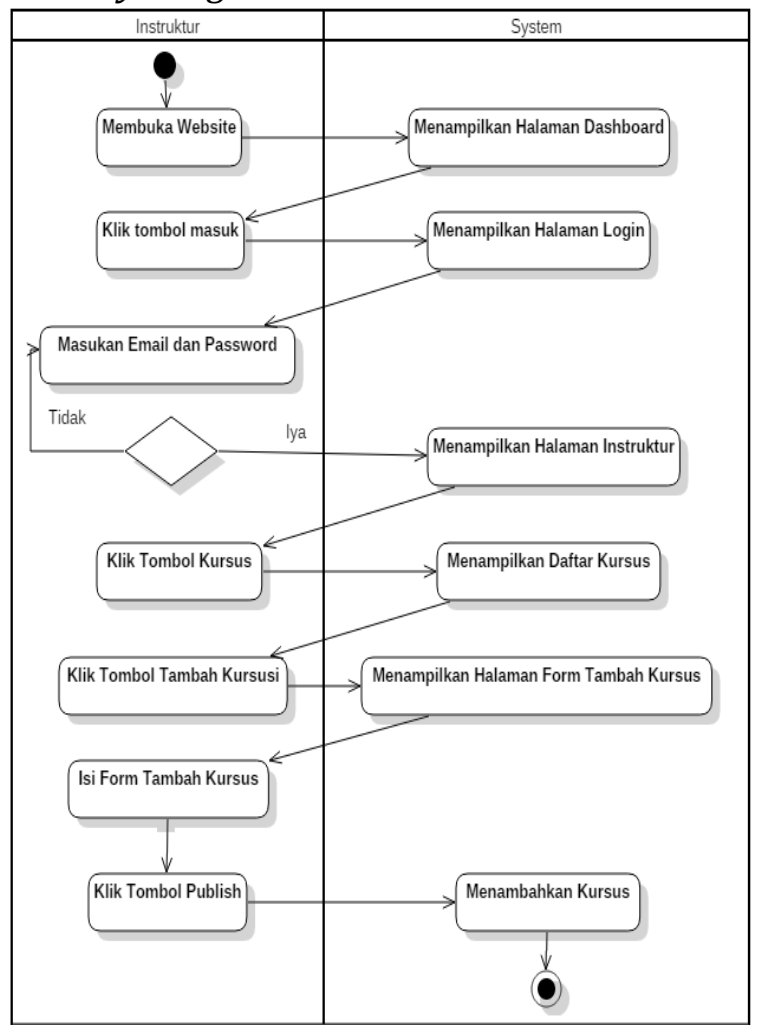

Gambar 10. Activity Diagram Instruktur Membuat Kursus

\section{c. Sequence Diagram}

Sequence Diagram Aplikasi Learning Management System Ini (LMS) dibagi menjadi 4 sequence diagram yaitu: 
1. Sequence Diagram User Login

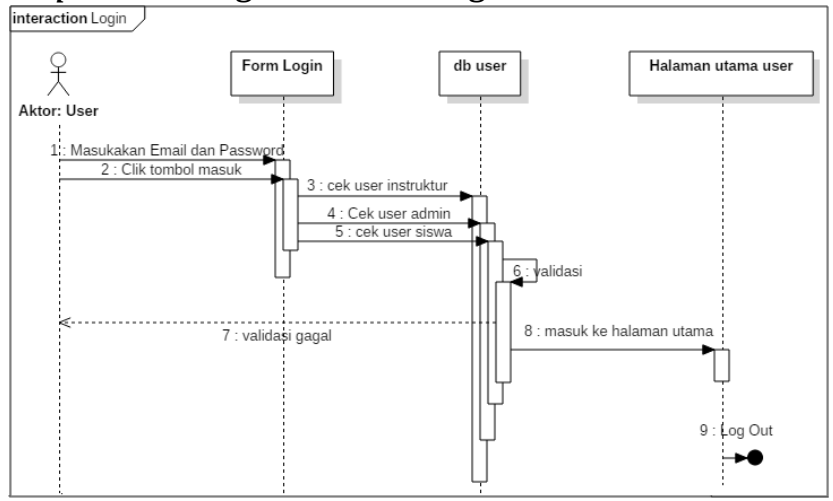

Gambar 11. Sequence Diagram User Login

2. Sequence Diagram Admin CRUD User

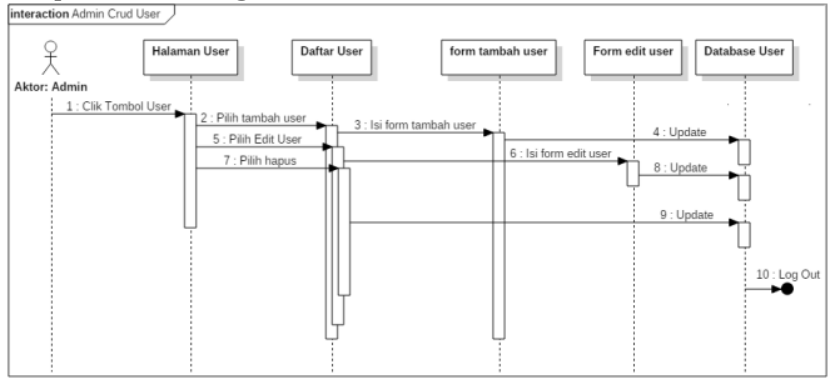

Gambar 12. Sequence Diagram Admin CRUD Use

3. Sequence Diagram Instruktur CRUD Kursus

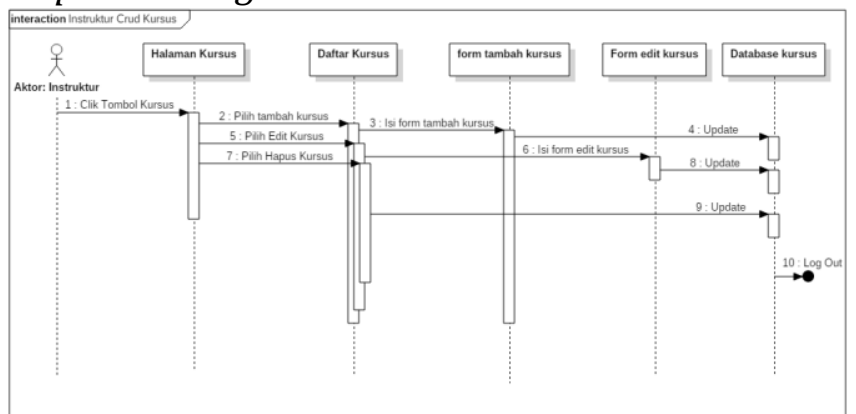

Gambar 13. Sequence Diagram Instruktur CRUD Kursus

4. Sequence Diagram Siswa Mengikuti Kursus

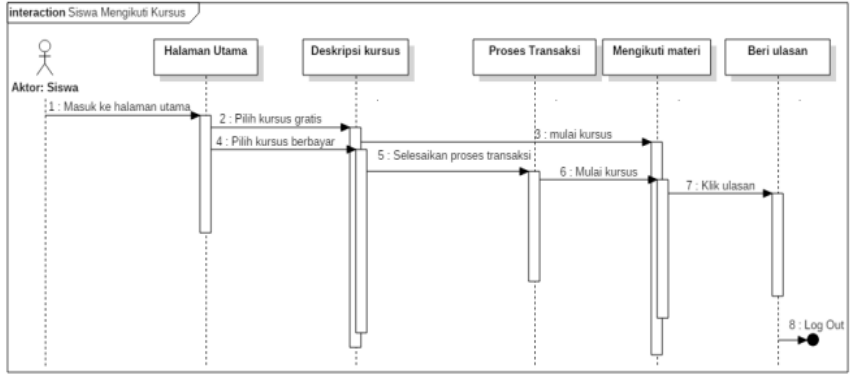

Gambar 14. Sequence Diagram Siswa Mengikuti Kursus 


\section{d. Class Diagram}

Berdasarkan Pemetaan Tabel diatas maka terbentuklah class diagram pada Learning Management System di lembaga kursus dan pelatihan Bumi Kreatif Institute seperti gambar dibawah ini.

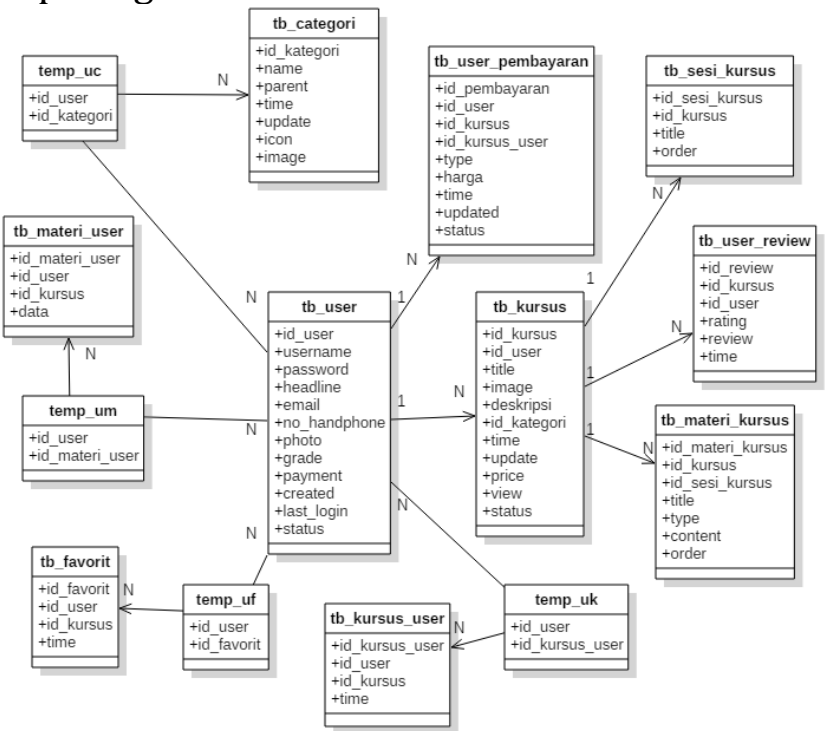

Gambar 15. Class Diagram

\section{Implementasi Sistem}

Dalam tahap ini penulis akan menampilkan dan menjelasakan dari perancangan antarmuka aplikasi LMS LKP Bumi Kreatif Institute, dalam hal ini terbagi menjadi tiga bagian, yaitu perancangan antarmuka admin, siswa dan instruktur. Dalam tiga tahapan tersebut diharapkan pengguna aplikasi LMS LKP Bumi Kreatif Institute dapat memahami beberapa fitur yang ada di dalamnya sehingga pengguna dapat mempermudah untuk menjalankannya. Berikutn gambar dan penjelannya seperti dibawah ini:

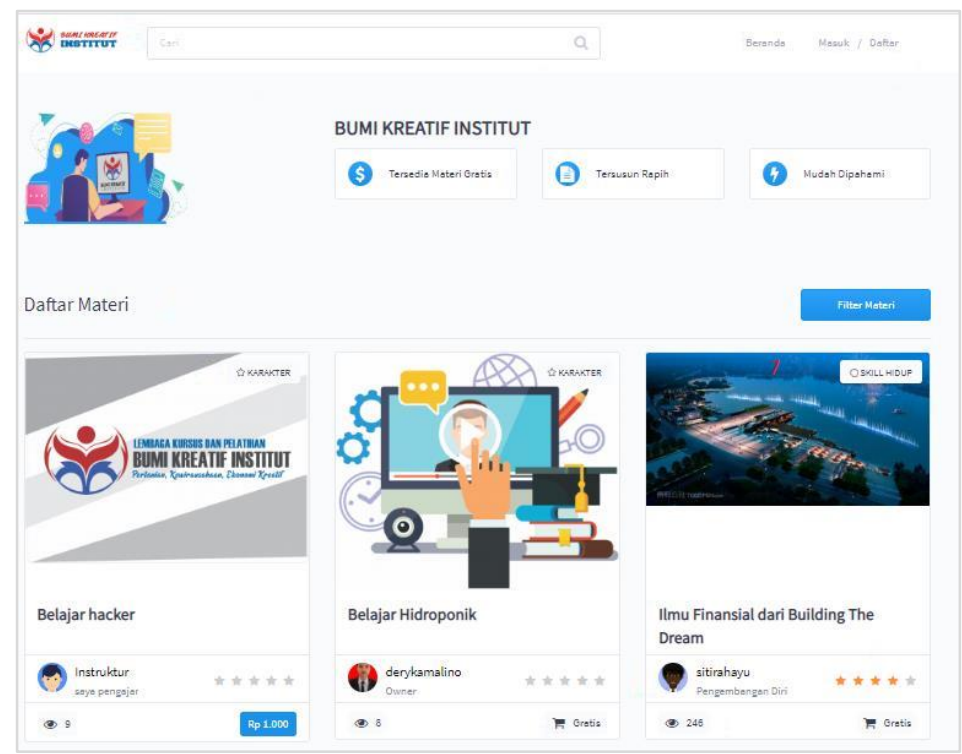

Gambar 16. Halaman Beranda 


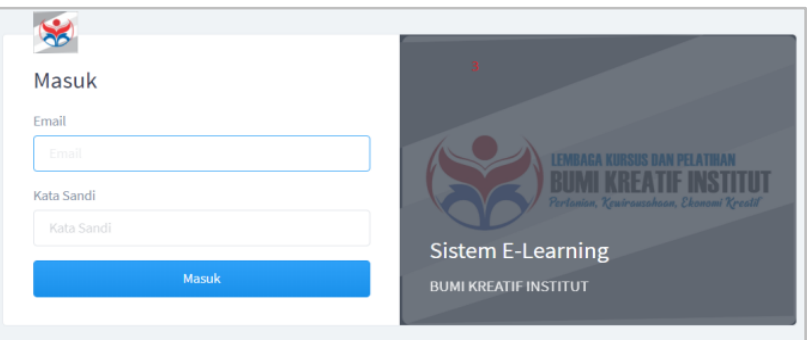

Gambar 17. Halaman Utama Siswa Login Di Menu Kelas

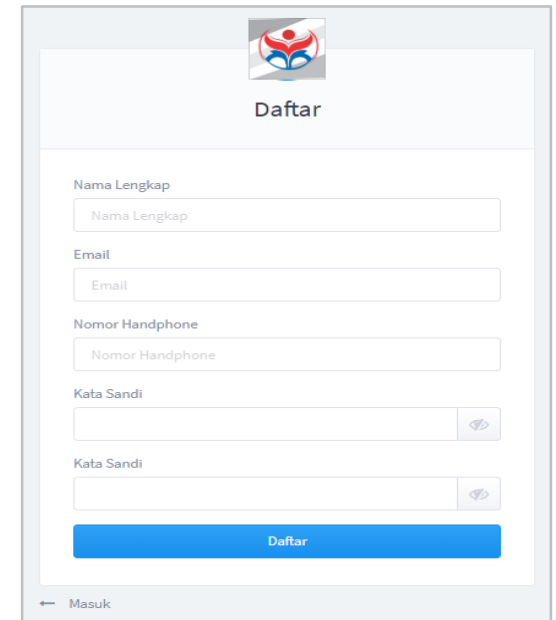

Gambar 18. Halaman Registrasi Siswa

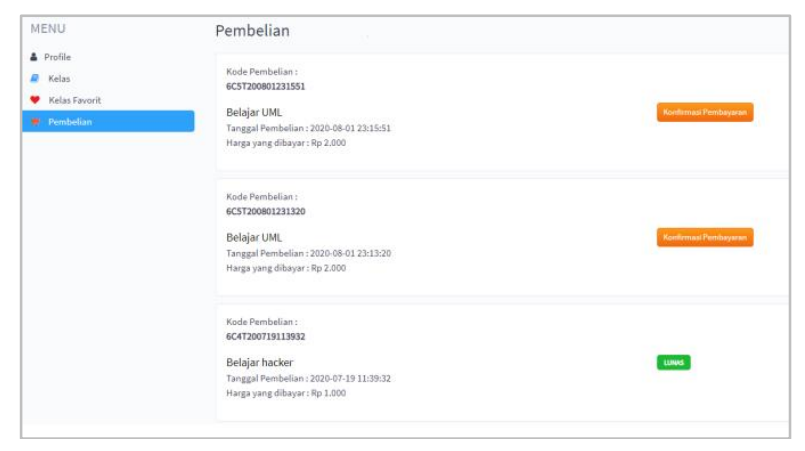

Gambar 19. Halaman Menu Pembelian Di Login

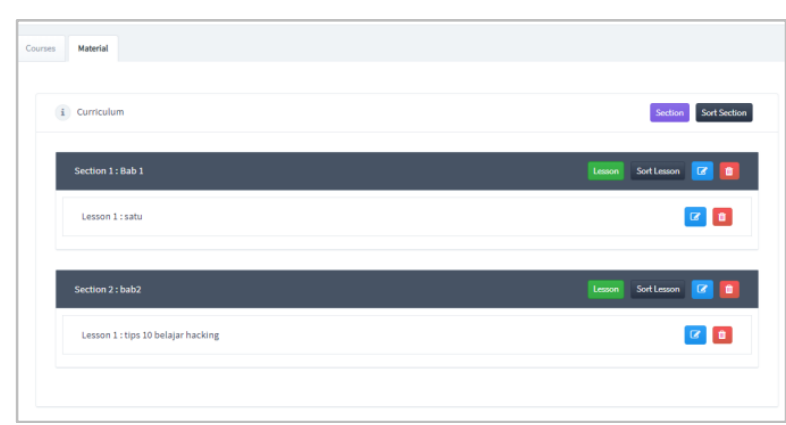

Gambar 20. Halaman Tambah Materi 
20 | Justek: Jurnal Sains Dan Teknologi | Vol. 3, No. 1, Mei 2020, Hal. 9-23

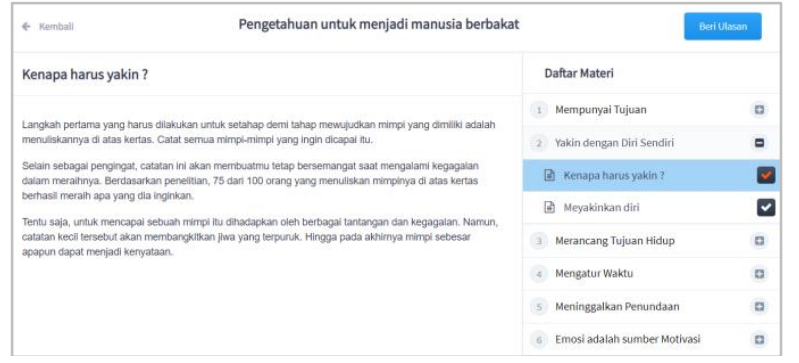

Gambar 21. Halaman User Mengikuti Materi Kursus

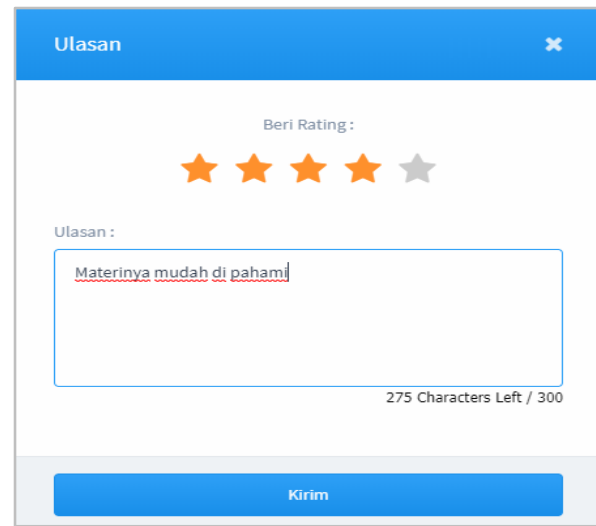

Gambar 22. Halaman Untuk Memberikan Ulasan Kursus

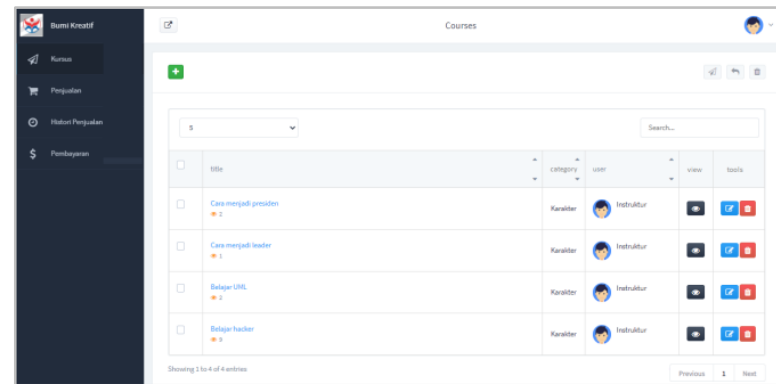

Gambar 23. Halaman Utama Instruktur

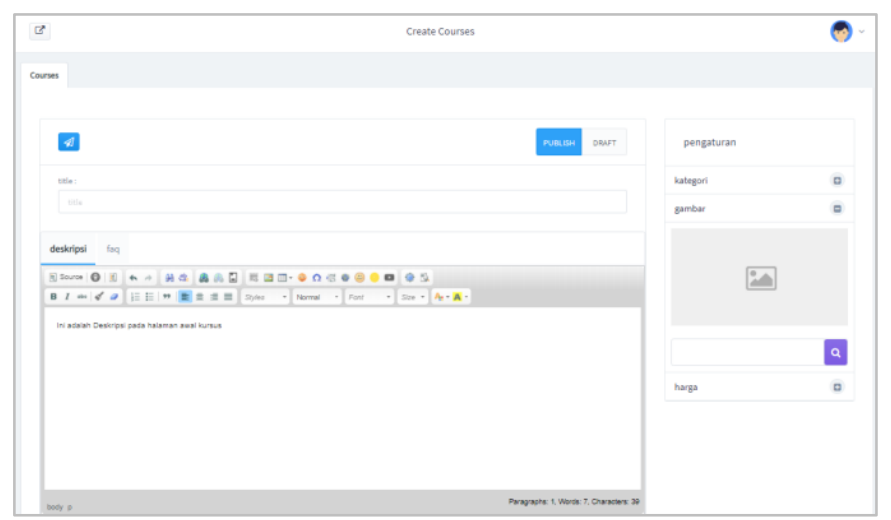

Gambar 24. Halaman Tambah Kursus 


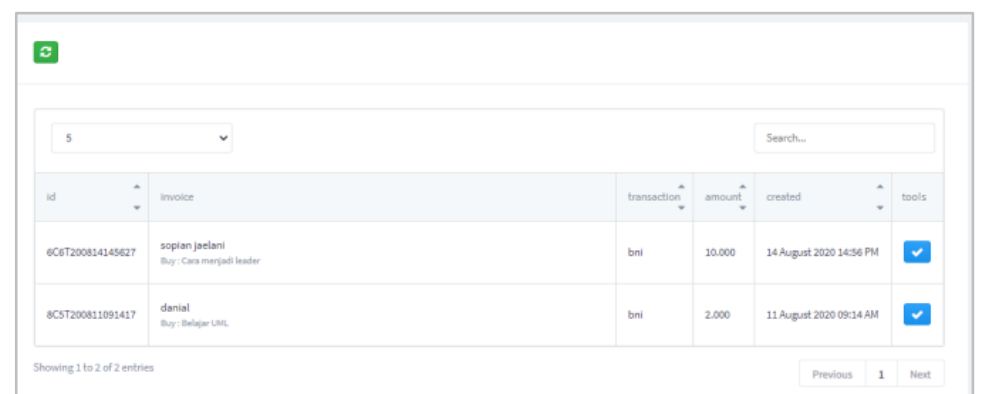

Gambar 25. Halaman Konfirmasi Pembayaran

\section{Pengujian Blackbox}

Berdasarkan hasil pengujian dengan metode Black Box Testing maka kasus uji sample diatas dapat ditarik kesimpulan bahwa perangkat lunak bebas dari kesalahan sintaks dan secara fungsional atapun dari segi usability mengeluarkan hasil yang sesuai dengan yang diharapkan.

\section{Pengujian Usability Testing}

Pengujian ini dilakukan pada penerapan hasil dari rancang bangun Learning Management System lembaga kursus dan pelatihan Bumi Kreatif Institute, testing ini akan dilakukan dengan menjalankan aplikasi yang telah di buat dengan melakukan pengujian yang telah disediakan oleh pembuat system ke pengguna, dari mulai melakukan pendaftaran siswa, login, memesan kursus, menambah kursus favorit, melakukan transaksi pembayaran, mengikuti kursus, dan memberikan ulasan. Berikut pada table 7 merupakan task usability testing yang dimaksud.

Tabel 2. Task Usability Testing

\begin{tabular}{ll}
\hline No & Tugas/Task \\
\hline 1 & Mendaftar Akun Siswa \\
2 & Melakukan Login \\
3 & Menambahkan Kursus Favorit \\
4 & Memesan Kursus \\
5 & Melakukan Transaksi Pembayaran \\
6 & Mengikuti Kursus \\
7 & Memberikan Ulasan \\
\hline
\end{tabular}

Setelah menyebar kuesioner lalu menghasilkan plot berdasarkan kelima aspek tersebut diatas terhadap 10 pertanyaan kuesioner yang dapat dilihat pada tabel 5 dibawah ini:

Tabel 3. Plot Aspek Usability

\begin{tabular}{|c|c|c|c|c|c|c|}
\hline \multirow[b]{2}{*}{ No } & \multirow[b]{2}{*}{ Pertanyaan } & \multicolumn{5}{|c|}{ Aspek Usability } \\
\hline & & 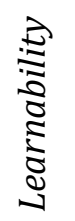 & 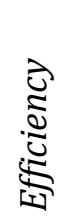 & 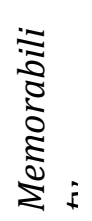 & $\sum_{0}^{y}$ & 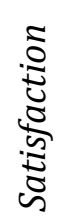 \\
\hline 1 & Apakah pendaftaran akun mudah dilakukan? & & & & & \\
\hline 2 & Apakah proses login mudah dilakukan? & & & & & \\
\hline 3 & Apakah menambah kursus favorit mudahn dilakukan? & & & & & \\
\hline 4 & Apakah langkah pemesanan kursus mudah dilakukan? & & & & & \\
\hline 5 & Apakah proses pembayaran mudah dilakukan & & & & & \\
\hline
\end{tabular}


6 Apakah proses mengikuti kursus mudah di mengerti?

$7 \quad$ Apakah proses pemberian ulasan mudah dilakukan?

8 Apakah desain antarmuka mudah dimengerti?

9 Apakah desain website nyaman dilihat?

10 Apakah semua fungsi yang ada berjalan dengan baik dan mudah dimengerti?

Berdasarkan hasil Usability testing maka diperoleh hasil rekap sebagaimana ditunjukkan Tabel 7 berikut:

Tabel 4. Rekap Nilai Usability

\begin{tabular}{lllllllll}
\hline No & Pertanyaan & STS & TS & N & S & SS & Nilai & Presentase \\
\hline 1 & P1 & 0 & 0 & 0 & 3 & 7 & 4,7 & $94 \%$ \\
2 & P2 & 0 & 0 & 0 & 3 & 7 & 4,7 & $94 \%$ \\
3 & P3 & 0 & 0 & 0 & 6 & 4 & 4,4 & $88 \%$ \\
4 & P4 & 0 & 0 & 1 & 5 & 4 & 4,3 & $86 \%$ \\
5 & P5 & 0 & 0 & 1 & 8 & 1 & 4,0 & $80 \%$ \\
6 & P6 & 0 & 0 & 3 & 6 & 1 & 3,8 & $76 \%$ \\
7 & P7 & 0 & 0 & 1 & 7 & 2 & 4,1 & $82 \%$ \\
8 & P8 & 0 & 0 & 0 & 10 & 0 & 4,0 & $80 \%$ \\
9 & P9 & 0 & 0 & 0 & 8 & 2 & 4,2 & $84 \%$ \\
10 & P10 & 0 & 0 & 0 & 5 & 5 & 4,5 & $90 \%$ \\
\hline
\end{tabular}

Berikut merupakan gambaran visual dalam bentuk grafis atau diagram dari hasil penilaian kuesioner.

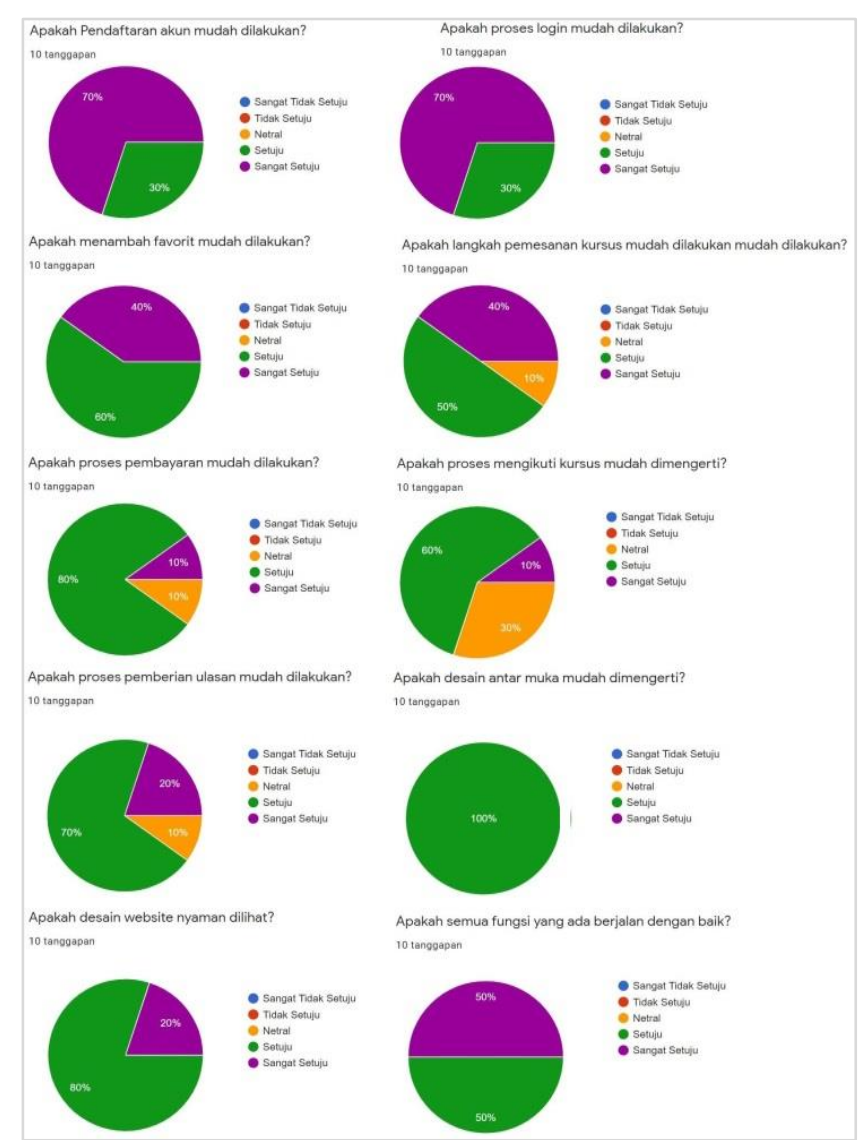

Gambar 26. Diagram Hasil Olah Kuesioner 


\section{SIMPULAN DAN SARAN}

Berikut beberapa kesimpulan hasil dari penelitian yang telah penulis laksanakan (1) Hasil dari rekap nilai usability menunjukan keseluruhan atribut memiliki nilai penerimaan usability oleh pengguna rata-rata 4,27 yang berati telah memiliki nilai aspek usability yang baik; (2) Penulis telah menganalisis LMS di LKP Bumi Kreatif Institute; (3) Penulis berhasil merancang LMS di LKP Bumi Kreatif Institute; (4) Aplikasi LMS di LKP Bumi Kreatif Institute berhasil dibangun. Saran yang dapat diambil dari penulisan dalam pembuatan Aplikasi Learning Management System untuk penelitian selanjuatnya adalah (1) Adanya peningkatan tingkat keamanan system informasi; (2) Perlu adanya pengembangan untuk flatform versi Android; (3) Diharapkan adanya penambahan fitur video call yang dapat digunakan untuk ulasan atau berdiskusi antara instruktur dan siswa; (4) Dalam segi pembayaran diharapkan adanya penambahan fitur virtual account sehingga siswa dapat membeli kursus berbayar bisa lewat mini market terdekat; (5) Dalam segi pembelajaran diharapkan adanya penambahan fitur tugas sehingga instruktur dapat mengetahui kemajuan belajar siswa.

\section{REFERENSI}

Fahrurrozi, I., \& Azhari, S. N. (2013). Proses Pemodelan Software Dengan Metode Waterfall dan Extreme Programming: Studi Perbandingan. Jurnal Online STMIK EL RAHMA.

Firman, F., \& Rahayu, S. (2020). Pembelajaran Online di Tengah Pandemi Covid-19. Indonesian Journal of Educational Science (IJES). https://doi.org/10.31605/ijes.v2i2.659

Ismail, L., \& Sinen, R. (2017). Penerapan Sistem Informasi Manajemen Pendidikan Dalam Proses Pembelajaran di SMP Negeri 21 Makassar. Idaarah: Jurnal Manajemen Pendidikan, 1. https://doi.org/10.24252/idaarah.v1i2.4272

Joshi, A., Kale, S., Chandel, S., \& Pal, D. (2015). Likert Scale: Explored and Explained. British Journal of Applied Science \& Technology, 7, 396-403. https://doi.org/10.9734/BJAST/2015/14975

Muhammad, T. (2017). Perancangan Learning Management System Menggunakan Konsep Computer Supported Collaborative Learning. Jurnal Produktif.

Nidhra, S. (2012). Black Box and White Box Testing Techniques - A Literature Review. International Journal of Embedded Systems and Applications. https://doi.org/10.5121/ijesa.2012.2204

Poerwanto, P., \& Shambodo, Y. (2020). Revolusi Industri 4.0: Googelisasi Industri Pariwisata dan Industri Kreatif. Journal of Tourism and Creativity, 4, 59. https://doi.org/10.19184/jtc.v4i1.16956

Raharja, S. (2014). Model Pembelajaran Berbasis Learning Management System Dengan Pengembangan Software Moodle di SMA Negeri Kota Yogyakarta. Jurnal Kependidikan: Penelitian Inovasi Pembelajaran, 41(1). https://doi.org/10.21831/jk.v41i1.504

Sastradipraja, C., \& Barokah, R. (2020). Rancang Bangun Sistem Informasi Kualitas Layanan Terhadap Kepuasan Pasien Menggunakan Metode Customer Satisfaction Index. Jurnal Ilmiah Flash, 6(2), 16-27. https://doi.org/10.32511/jiflash.v4i1.204

Shuttleworth, M. (2009). What Is A Literature Review?

Supriyatna, A. (2018). Penerapan Usability Testing Untuk Pengukuran. Jurnal Ilmiah Teknologi Informasi Dan Sains (TeknoIS) Volume.

Suryati. (2016). Sistem Manajemen Pembelajaran Online, Melalui. Jurnal Raden Fatah.

Tantoni, A., Ashari, M., \& Zaen, M. (2020). Analisis Dan Implementasi Jaringan Komputer Brembuk.Net Sebagai Rt/Rw.Net Untuk Mendukung E-Commerce Pada Desa Masbagik Utara. MATRIK: Jurnal Manajemen, Teknik Informatika Dan Rekayasa Komputer, 19, 312320. https://doi.org/10.30812/matrik.v19i2.591

Widhiartha, P. A. (2009). Pemanfaatan E-Learning Sebagai Alternatif Pengganti Pelatihan Tatap Muka Bagi Pendidik Dan Tenaga Kependidikan Pendidikan Nonformal. JIV. https://doi.org/10.21009/jiv.0402.7 
24 | Justek : Jurnal Sains Dan Teknologi | Vol. 3, No. 1, Mei 2020, Hal. 9-23 